\title{
CORRECTION TO: INVESTIGATING THE TRIBOLOGICAL BEHAVIOR OF ALUMINUM ALLOYS PRODUCED BY A NOVEL METHOD: GAS-INDUCED SEMI-SOLID (GISS) CASTING TECHNOLOGY
}

\author{
Yilmaz Tezgel, Ipek Tunc, and Ozgul Keles \\ Oguzhan Kaya and Alper Yesilcubuk \\ Arcelik Central R\&D, Cayirova Campus, 34950 Tuzla, Istanbul, Turkey

\section{Muammer Mutlu} \\ Mita Kalip ve Dokum San. A.S, 34520 Beylikduzu, Istanbul, Turkey
}

Department of Metallurgical and Materials Engineering, Istanbul Technical University, 34469 Maslak, Istanbul, Turkey

Copyright $(\subset) 2021$ American Foundry Society

https://doi.org/10.1007/s40962-021-00639-y

\section{Correction to: International Journal of Metalcasting https://doi.org/10.1007/s40962-021-00619-2}

Alper Yesilcubuk has been added as a corresponding author to the original article.
Publisher's Note Springer Nature remains neutral with regard to jurisdictional claims in published maps and institutional affiliations. 